\title{
LAPAROSCOPIC ADRENALECTOMY: FIRST SINGLE-CENTER EXPERIENCE IN THE BALKANS
}

\section{Zivko Popov 1, 2, 6, 7*, Nikola Jankulovski ${ }^{3}$, Oliver Stankov ${ }^{2}$, Sotir Stavridis², Skender Saidi², Marjan Kuzmanoski ${ }^{2,6}$, Igor Chipurovski ${ }^{6,7}$ Sasho Banev $^{4}$, Branka Krstevska ${ }^{5}$, Ognen Ivanovski ${ }^{2}$, Chedomir Dimitrovski ${ }^{5}$}

\author{
${ }^{1}$ Macedonian Academy of Sciences and Arts, Skopje, R. Macedonia \\ ${ }^{2}$ University Clinic of Urology, Skopje, R. Macedonia \\ ${ }^{3}$ University Clinic of Digestive surgery, Skopje, R. Macedonia \\ ${ }^{4}$ Institute of Pathology, Skopje, R. Macedonia \\ ${ }^{5}$ Endocrinology and Metabolic Disorders Clinic, Medical Faculty, Ss. Cyril and Methodius University, \\ Skopje, R. Macedonia \\ ${ }^{6}$ Special Hospital for Surgical Diseases Filip Vtori, Skopje, R. Macedonia \\ ${ }^{7}$ General Hospital Remedica, Skopje, R. Macedonia
}

Corresponding Author: Popov Zivko, MD, PhD, Macedonian Academy of Science and Art, Krste Misirkov br 2, 1000 Skopje, Republic of Macedonia; Phone: + 389 (0)2 723070 70; E-mail: zivkopopov2000@yahoo.com

\begin{abstract}
Introduction: Laparoscopic adrenalectomy has become the preferred approach for removal of the adrenal gland for the management of benign or malignant functioning or nonfunctioning adrenal masses. We aimed to present our initial experience with this procedure. In addition, we compare the clinical outcomes of laparoscopic (LA) vs. the open adrenalectomies (OA) performed at our institutions. Also we report a case of successful laparoscopic treatment of splenic artery aneurism involving laparoscopic splenectomy.

Patients and Methods: A retrospective analysis of the data of all patients who underwent adrenalectomy at three institutions, over the last 12-year period, since the laparoscopic adrenal surgery was introduced in our country. All patients were assessed regarding the demographic data, hormonal status, operative time, estimated blood loss, complications, size of the tumor, number of patients requiring blood transfusion, hospital stay and conversion to open surgery for LA.

Results: Thirty five consecutive patients, aged from 33 to 67 (average age 54 years) underwent unilateral LA adrenalectomy during the study period including 14 right and 21 left sided. The laparoscopic procedure was successfully completed in all except 4 cases, which were converted to open surgery to control bleeding from the avulsed adrenal veins. LA proved superior to OA, resulting in less estimated blood loss, shorter operating time, shorter time to resumption of oral intake, shorter postoperative hospital stay and less analgesic requirements. During the follow-up of 3 to 36 months no tumor recurrence and/or metastasis developed.

Conclusions: Our results concur with other retrospective reviews comparing laparoscopic and open adrenalectomy, demonstrating unequivocal advantages in terms of reduced length of hospital stay, blood loss, return of bowel function, functional recovery and post-operative morbidity.
\end{abstract}




\section{Introduction}

The surgical approach to the adrenal gland varies widely according to the size and the endocrine nature of the tumor, with the anterior transperitoneal, posterior and flank extraperitoneal and thoracoabdominal approaches being preferable in individual cases. The incision of open adrenalectomy is quite large, leading to significant postoperative pain that may necessitate the use of epidural catheters, with consequent increased wound morbidities, cosmetic defect and longer hospital stay [1, 2]. Morbidity after open adrenalectomy has been reported to be as high as $40 \%$, with the mortality rate in the range of $2 \%$ to $4 \%$ [1]. However, the small size of the adrenal gland, the benign nature of most adrenal tumors, and the difficulty of gaining access to the organ by open surgery, together with the improvement of the cross-sectional imaging (CT and MRI) to define the lesion preoperatively, make the laparoscopic approach particularly suitable for adrenalectomy [3].

Twenty two years ago Gagner et al. [4] reported their first experience with the transperitoneal laparoscopic adrenalectomy (LA) in three cases of benign adrenal pathology. In the early 1990s the indications for LA included small benign lesions [5], with larger lesions or phaeochromocytomas being approached very cautiously, with malignancy being considered an absolute contraindication. The indications included various pathological conditions, e.g. aldosterone-producing adenoma, Cushing's disease, nonfunctioning adenoma and other rare pathologies (adrenal cyst and myelolipoma). The groups in favor of the laparoscopic surgery were gaining experience rapidly and many early contraindications (e.g. obesity, phaeochromocytoma, large adrenal lesions, previous abdominal surgery and malignancy) proved not to be absolute but rather related to the team's surgical skills [6].

This type of operation is presently considered to be the 'standard of care' for most adrenal diseases requiring surgery because of its functional efficacy and all the typical advan- tages inherent in minimally invasive surgery. More than 20 years after the initial description of this surgical procedure we present one of the first LA experience in the Balkan region, with particular focus on the indications, results and complications, comparing these data with those from the open surgery performed in our Institution. In addition, we present a case of giant splenic artery aneurism mimicking adrenal tumor, treated successfully by laparoscopic approach.

\section{Patients and methods}

During the study period, thirty five consecutive patients, aged from 33 to 67 (average age 54 years) underwent unilateral LA adrenalectomy in three institutions (University Clinic of Urology, Special Hospital for Surgical Diseases Filip Vtori and General Hospital Remedika) including 14 right and 21 left sided. Abdominal CT and ultrasound were the radiologic tool for diagnosis of the adrenal masses, unless otherwise indicated. There were $31 \mathrm{OA}$ performed mostly in the period before LA was introduced. The majority of LA procedures were performed by a single surgeon $(\mathrm{ZP})$ in three institutions with the majority of cases at the University Clinic of Urology. All patients were assessed regarding the demographic data, complete endocrinological status, operative time, estimated blood loss, complications, size of the tumor, number of patients requiring blood transfusion, hospital stay and conversion to open surgery for LA. The postoperative course was carefully reported, especially concerning the time of initial eating and ambulation, as well as any postoperative complications and the length of the hospital stay.

The transperitoneal approach for laparoscopic adrenalectomy was used in all cases of LA. The surgical technique was that described by Hamilton [7]. Briefly, we routinely employ a $60^{\circ}$ flank position, with the bed flexed, in order to elevate the surgical area and widen the space between the costal arch and the iliac crest for adequate port placement. Figure 1 shows 
the exact placement of the trocars. We prefer this approach since the anatomic landmarks for a safe procedure are well visualized. In addition, the surgeon (ZP) has already gained skills in laparoscopic identification, inspection, and dissection of intraabdominal organs and frequently has approached and removed kidneys. Our primary target was early control of the main adrenal vein. This had two benefits: it avoided attacks of hypertension resulting from manipulation of the adrenal gland, and it facilitated complete mobilization of the gland, as the adrenal vein is the main structure anchoring the gland in its place [2]. The exposure of the inferior vena cava (IVC) on the right side and the left renal vein on the left side was used for early control of the main adrenal vein. On the right side, after the liver has been lifted, the posterior peritoneum was incised to expose the inferior vena cava and the adrenal gland (Figure 2). Because of the small size of the adrenal vessels, vascular endoclips were sufficient for their control (Figure 3). The dissection progresses superomedially, laterally, posteriorly, and, finally, posterorly. After the dissection of the adrenal mass was completed, it was entrapped in a plastic bag (Figure 4), then retrieved via an extended muscle-splitting portside incision. The left sided LA mostly was performed using 3 ports, whereas for the right-sided LA we used 4 ports.

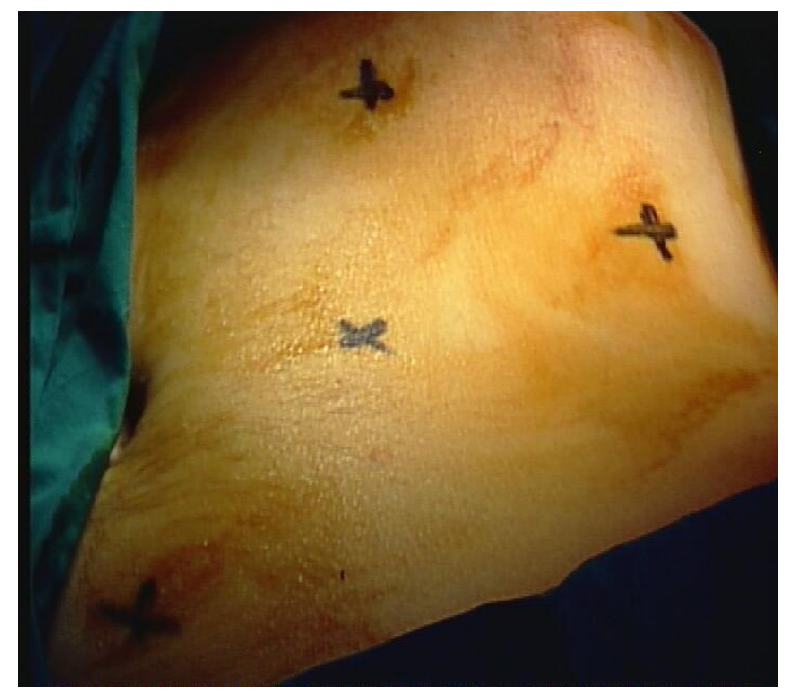

Figure 1 - Flank semilateral position and exact placement of the trocars (left sided adrenalectomy)

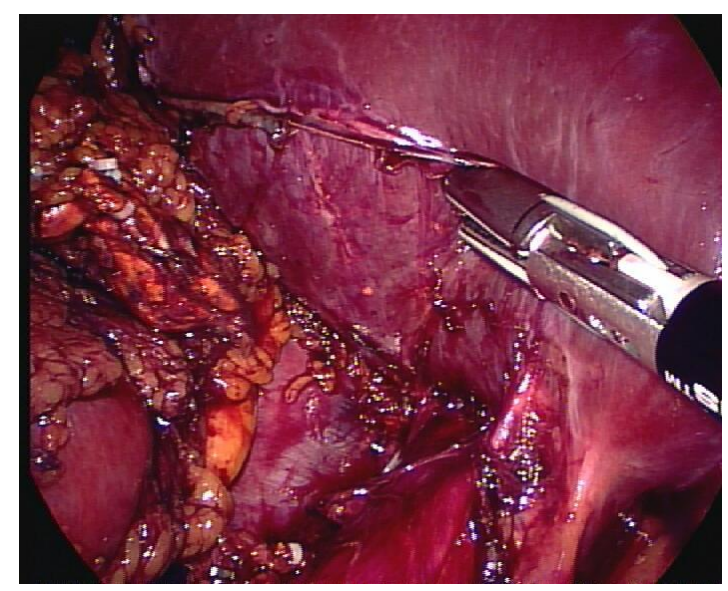

Figure 2 - Incision of the posterior peritoneum To expose the inferior vena cava and the adrenal gland

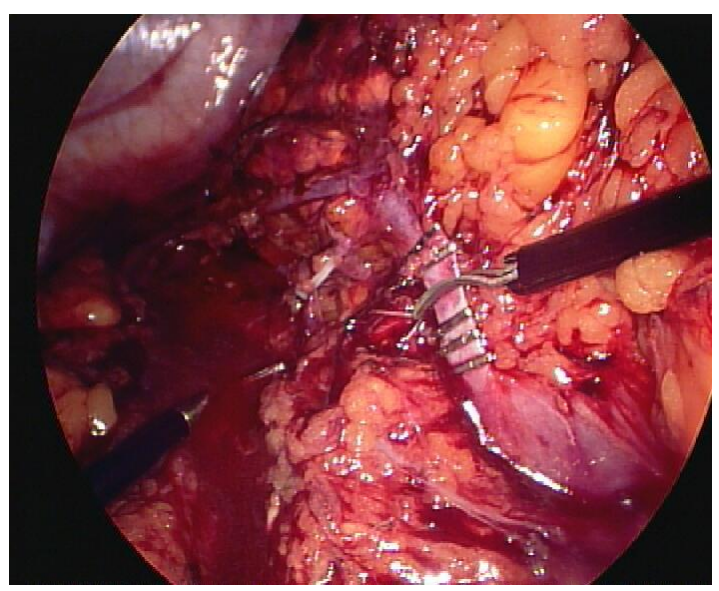

Figure 3 -Division of the adrenal vein after dissection and clipping

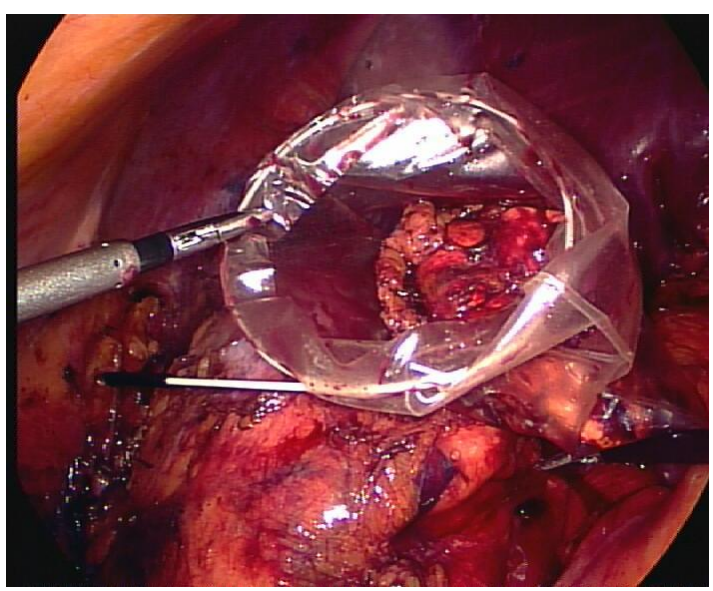

Figure 4 - Adrenal mass entrapped in a plastic bag

\section{Statistical analysis}

\section{Results}

The laparoscopic procedure was successsfully completed in all cases except in 4, which was converted to open surgery due to a bleeding from the avulsed adrenal vein that could 
not be controlled laporoscopically. The definitive histopathological diagnosis for LA included: Conn's syndrome (5 patients), Cushing's syndrome (13 patients), pheochromocytoma (5 patients), incidentaloma (11 patients) and other tumors (1 patients). (Table 1). Other 31 cases were performed via transabdominal subcostal approach. The definitive histopathological diagnosis for OA were: Conn's syndrome (4 patients), $\mathrm{Cu}-$ shing's syndrome (10 patients), pheochromocytoma (4 patients), incidentaloma (7 patients), malignancy between one metastatic RCC (3 patients), suprarenal cyst ( 2 patients) and oncocytoma (1 patient) (Table 1$)$.

Table 1

Postoperative histopathological diagnosis

\begin{tabular}{|c|c|c|}
\hline Histopathology & $\begin{array}{c}\text { Laparoscopic } \\
\text { adrenalectomy }\end{array}$ & $\begin{array}{c}\text { Open } \\
\text { adrenalectomy }\end{array}$ \\
\hline Conn`s syndrome & 5 & 4 \\
\hline Cushing syndrome & 13 & 10 \\
\hline Pheochromocytoma & 5 & 4 \\
\hline Incidentaloma & 11 & 7 \\
\hline $\begin{array}{c}\text { Malignancy (one } \\
\text { metastatic RCC) }\end{array}$ & $\mathrm{x}$ & 3 \\
\hline Suprarenal cyst & $\mathrm{x}$ & 2 \\
\hline Oncocytoma & $\mathrm{x}$ & 1 \\
\hline $\begin{array}{c}\text { Other (artery } \\
\text { aneurism) }\end{array}$ & 1 & $\mathrm{x}$ \\
\hline
\end{tabular}

Table 2
The demographic data of the patients were similar in the 2 groups (Table 2). There was no perioperative mortality in both groups. There was a significant difference between the average size of adrenal masses removed for the LA and the OA groups. LA proved superior to OA, resulting in less estimated blood loss, shorter operating time, shorter time to resumption of oral intake, shorter postoperative hospital stay and less analgesic requirements for patients satisfaction. In our LA group we had two patients with prolonged lymphous leakage resolved spontaneously, instead of the four patients with the same condition in the OA group, among them one with incapsular collection, drained percutaneously. During the follow-up of 3 to 36 months no tumor recurrence and/or metastasis developed. The average surgical time and postoperative stay for LA procedures was longer in the first half of the series than in the later operations ( $p<0.03$ ). However, median hospital charges were slightly greater in the LA group due to high cost of the material used for the LA procedures.

Demographic and operative data

\begin{tabular}{|c|c|c|c|}
\hline & $\begin{array}{c}\text { Laparoscopic } \\
\text { adrenalectomy }\end{array}$ & $\begin{array}{c}\text { Open } \\
\text { adrenalectomy }\end{array}$ & $\mathrm{p}$ \\
\hline Number & 35 & 31 & \\
\hline Female/male & $21 / 14$ & $17 / 14$ & $\mathrm{p}<0.5$ \\
\hline Size of the tumor (cm) range & $4.6 \pm 0.4$ & $6.1 \pm 0.7$ & $\mathrm{p}=\mathrm{NS}$ \\
\hline Mean surgical time (hours) & $2.9 \pm 0.9$ & $3.7 \pm 0.3$ & $\mathrm{p}<0.01$ \\
\hline Blood loss avg (ml) & $120(50-350)$ & $371(150-450)$ & $\mathrm{p}<0.001$ \\
\hline $\begin{array}{c}\text { Time to resumption of oral } \\
\text { intake (days) }\end{array}$ & 1.9 & 4.4 & $\mathrm{p}=0.01$ \\
\hline $\begin{array}{c}\text { Postoperative hospital stay } \\
\text { (days) }\end{array}$ & $3.9 \pm 0.5$ & $8.7 \pm 1.5$ & \\
\hline
\end{tabular}

The blood pressure returned to normal 3 months after the operation in $86 \%$ of the patients in the LA group and in $89 \%$ in the OA group. During the follow-up of 3 to 36 months no tumor recurrence and/or metastasis developed. Interestingly, one case presented with a large mass near the left adrenal gland and it was primarily diagnosed as of adrenal origin by means 
of spiral CT, ultrasound and magnetic resonance (MRI). It was the case of a 59 year old women with incidentally found tumor in the left adrenal gland. The endocrinological status was unremarkable. However, intra-operatively we found a large splenic artery aneurism which we successfully resected along with a laparoscopic splenectomy. The definitive histopathology diagnosis of this mass revealed a specimen consisting of $8.5 \mathrm{~cm}$ dilated portion of spleen artery with a maximum circumference of $7 \mathrm{~cm}$. The patient denied previous trauma, pancreatitis, portal hypertension, splenomegaly or collagen vascular disease.

\section{Discussion}

In the present study we present our initial experience with LA, with particular focus on indications, results and complications, comparing these data with those from the open surgery performed in our Institutions. To the best of our knowledge this is one of the first report of adrenal laparoscopy in the Balkan region. In addition, we present a successful resection of a giant splenic aneurism mimicking an adrenal tumor performed at the University Clinic of Urology.

At present, LA should be considered the 'platinum standard' for the treatment of the vast majority of adrenal diseases, including malignnancy that is confined to the organ [8]. In addition, LA can be performed safely and efficiently in patients with significant comorbidities and in patients with large adrenal tumors [9]. In the early series, the operative times were prolonged, but it quickly became clear that the operation was a safe and feasible procedure. Several large single-surgeon and single-institution studies demonstrated excellent results beyond the initial learning curve. For example, Suzuki and associates in 1999 reported 24 complications among 75 consecutive patients (32\%). Five patients $(6.6 \%)$ were converted to open surgery. The operative time was 227 minutes on the left and 210 minutes on the right with minimal blood loss [10]. Lezoche and colleagues have just recently reported their experience with 214 consecutive cases of laparoscopic transperitoneal adrenalectomy with a mean operating time of 80 minutes and a mean hospital stay of 2.5 days [6]. There were no deaths, $2 \%$ of complications, and $6 \%$ of conversions to open surgery. In our series the conversion rate $(11.42 \%)$ is in accordance with the literature. The hospitalization period in the first half of our series was $7.9 \pm 0.5$ days, which is quite long compared with other Centers $[2,11]$. The same is true for the operating time. The explanation is that majority of these patients were treated in a public / university hospital, where patients usually stay for longer periods for scientific or social reasons. We have been also very conservative with our LA patients in terms of discharge, similar to our early experience with laparoscopic living donor nephrectomies [12]. Thus, even though we tend to dismiss OA patients earlier than in prior years, we anticipate a further reduction in the mean hospital stay for our LA patients as well. In fact, this trend has already occurred, because many of our patients leave the hospital within 2 to 4 days after successful LA. Likewise, the average surgical time for LA procedures was longer in the first half of series then in the later operations $(\mathrm{p}<0.03)$.

Our results concur with other retrospecttive reviews comparing laparoscopic and open adrenalectomy, demonstrating unequivocal advantages in terms of reduced length of hospital stay, blood loss, return of bowel function functional recovery and post-operative morbidity. In contrast, we did not achieve cost savings for the laparoscopic approach; in fact, the charges were higher in this group. However, the operative and hospitalization costs represent only a fraction of the overall costs attributable to the medical care of these patients. Cost savings result from the quicker return to normal activities, shorter disability, and rapid return to society as compared to open procedures, although these savings may be more difficult to quantitate.

There have been only few cases of giant SAAs $>8 \mathrm{~cm}$ in diameter reported in the litera- 
ture. Moreover, only a few reports of successful laparoscopically resected SAA have appeared in the surgical literature. Saw et al. reported the first successful resection of a $2.5-\mathrm{cm}$ aneurysm with the patient in a supine position in April of 1994 [13]. Although a later description of a laparoscopically assisted SAA resection was published in 1997 [14], it was not until 1998 that Leung et al. reported the second successful laparoscopic resection of a SAA, the first using a full lateral approach [15]. Meinke et al. reported modified approach using a modification of the lateral approach described by Leung [16]. In addition, Reardom et al. have recently reported a series of 5 cases of successful attempts of laparoscopically splenic artery aneurysm resection involving laparoscopic splenectomy, aneurism ligation and aneurism resection [17]. However, all of these cases were diagnosed preoperatively which was not our case. All laboratory and radiological examinations performed by experienced doctors revealed a mass originating from the left adrenal gland. However, we did not perform an arteriography simply because we do not think it was necessary. A large SAA mimicking an adrenal tumor is a very rare occurrence and points out to a possible future diagnostic dilemma.

In conclusion, LA is not easier, quicker or cheaper; nor does it avoid the need for general anesthesia. It has taken considerable time and effort in the operating room to develop a safe and effective operation. This procedure frequently involves two or three consultants, a practice generally unheard of at our institution with regard to the traditional open procedures. This has had a negative impact on the resident experience, because it relates to an operation that is already plagued by low numbers especially in a small countries like the R. Macedonia.

\section{REFERENCES}

1. McLeod MK. Complications following adrenal surgery. J Natl Med Assoc. 1991; 83: 161-164.

2. El-Kappany HA, Shoma AM, El-Tabey NA, et al. Laparoscopic adrenalectomy: a single-center experience of 43 cases. J Endourol. 2005; 19: 1170-1173.
3. Lezoche E, Guerrieri M, Feliciotti F, et al. Anterior, lateral, and posterior retroperitoneal approaches in endoscopic adrenalectomy. Surg Endosc. 2002; 16: 96-99.

4. Gagner M, Lacroix A, Bolte E. Laparoscopic adrenalectomy in Cushing's syndrome and pheochromocytoma. N Engl J Med. 1992; 327: 1033.

5. Gagner M, Lacroix A, Prinz RA, et al. Early experience with laparoscopic approach for adrenalectomy. Surgery. 1993; 114: 1120-1124; discussion 1124-1125.

6. Lezoche E, Guerrieri M, Crosta F, et al. Perioperative results of 214 laparoscopic adrenalectomies by anterior transperitoneal approach. Surg Endosc. 2008; 22: 522-526.

7. Hamilton BD. Transperitoneal laparoscopic adrenalectomy. Urol Clin North Am. 2001; 28: 61-70.

8. Cobb WS, Kercher KW, Sing RF, et al. Laparoscopic adrenalectomy for malignancy. Am J Surg. 2005; 189: 405-411.

9. Chan JE, Meneghetti AT, Meloche RM, et al. Prospective comparison of early and late experience with laparoscopic adrenalectomy. Am J Surg. 2006; 191 : 682-686.

10. Suzuki K, Ushiyama T, Ihara H, et al. Complications of laparoscopic adrenalectomy in 75 patients treated by the same surgeon. Eur Urol. 1999; 36: 40-47.

11. Castilho LN, Mitre AI, Arap S. Laparoscopic adrenal surgery in a Brazilian center. J Endourol. 2003; 17: 11-18.

12. Popov Z, Ivanovski N, Cakalaroski K, et al. [Coelioscopic renal prelevement on living donor. The first four cases in Republic of Macedonia]. Prog Urol. 2005; 15: 1227-1228.

13. Saw EC, Ku W, Ramachandra S. Laparoscopic resection of a splenic artery aneurysm. J Laparoendosc Surg. 1993; 3: 167-171.

14. Watanabe Y, Sato M, Abe Y, et al. Three-dimensional arterial computed tomography and laparoscope-assisted splenectomy as a minimally invasive examination and treatment of splenic aneurysms. J Laparoendosc Adv Surg Tech A. 1997; 7: 183-186.

15. Leung KL, Kwong KH, Tam YH, et al. Laparoscopic resection of splenic artery aneurysm. Surg Endosc. 1998; 12: 53.

16. Meinke AK, Floch NR, Dicorato MP. Laparoscopic options in the treatment of splenic artery aneurysms. Surg Endosc. 2002; 16: 1107.

17. Reardon PR, Otah E, Craig ES, et al. Laparoscopic resection of splenic artery aneurysms. Surg Endosc. 2005; 19: 488-493. 
Резиме

\section{ЛАПАРОСКОПСКА АДРЕНАЛЕКТОМИЈА: ПРВО ИСКУСТВО НА ЕДЕН ЦЕНТАР НА БАЛКАНОТ}

\section{Живко Попов 1, 2, 6, 7*, Никола Јанкуловски ${ }^{3}$, Оливер Станков ${ }^{2}$, Сотир Ставридис ${ }^{2}$, Скендер Саиди ${ }^{2}$, Марјан Кузманоски ${ }^{2,6}$, Игор Чипуровски ${ }^{6,7}$, Сашо Банев ${ }^{4}$, Бранка Крстевска ${ }^{5}$, Огнен Ивановски ${ }^{2}$, Чедомир Димитровски}

${ }^{1}$ Македонска академија на науките и уметностите, Скопје, Р. Македонија

${ }^{2}$ Универзитетска клиника за урологија, Скопје, Р. Македонија

${ }^{3}$ Универзитетска клиника за дигестивна хирургија, Скопје, Р. Македонија

${ }^{4}$ Институт за патологија, Скопје, Р. Македонија

${ }^{5}$ Универзитетска клиника за ендокринологија и метаболички болести, Медицински факултет, Универзитет „Св. Кирил и Методиј“, Скопје, Р. Македонија

${ }^{6}$ Специјална болница за хируршки болести „Филип Втори“, Скопје, Р. Македонија ${ }^{7}$ Општа болница „Ремедика“, Скопје, Р. Македонија

Boвeg: Лапароскопската адреналектомија претставува префериран пристап за отстранување на надбубрежната жлезда при решавање на бенигни или малигни, функционирачки или нефункционирачки, надбубрежни маси. Цел на оваа студија е да го презентираме нашето почетно искуство со оваа процедура. Како додаток, ги компарираме клиничките резултати на лапароскопските (LA) наспроти отворените адреналектомии (OA) изведени во нашите институции.
Исто така, реферираме и еден случај на успешен лапароскопски третман на аневризма на лиеналната артерија, проследен со лапароскопска спленектомија.

Пациенити и мет̄оgи: Ретроспективна анализа на податоците на сите пациенти подложени на адреналектомија во трите институции (Универзитетска клиника за урологија, Специјална болница за хируршки болести „Филип Втори“ и Општа болница „Ремедика“, Скопје, Македонија) во текот на последниот дванаесетгодишен период, откако лапароскопската адренална хирургија беше воведена во нашата земја. Сите пациенти беа проценети во однос на демографските податоци, хормоналниот статус, оперативното време, крвната загуба, компликациите, димензиите на туморот, бројот на пациенти со трансфузија на крв, болничкото лежење и конверзијата од лапароскопска во отворена хирургија.

Резулйайи: Последователно, триесет и пет пациенти беа подложени на еднострана LA за време на периодот на оваа студија, вклучувајќи 14 деснострани и 21 левострана. Лапароскопската процедура беше со успех комплетирана кај сите, освен кај четири случаи, кај кои е направена конверзија во отворена хирургија за да се контролира крвавењето од оттргнати адренални вени. LA се покажа како подобра од OA, како резултат на помала крвна загуба, пократко време на операција, пократко време на преминување кон исхрана и течности преку уста, пократко болничко лежење и помали потреби од аналгетици. За време на следењето на пациентите во период од три до 36 месеци, нема повторна појава на тумор и/или развој на метастатски депозити.

Клучни зборови: надбубрежна жлезда, лапароскопија, хирургија 